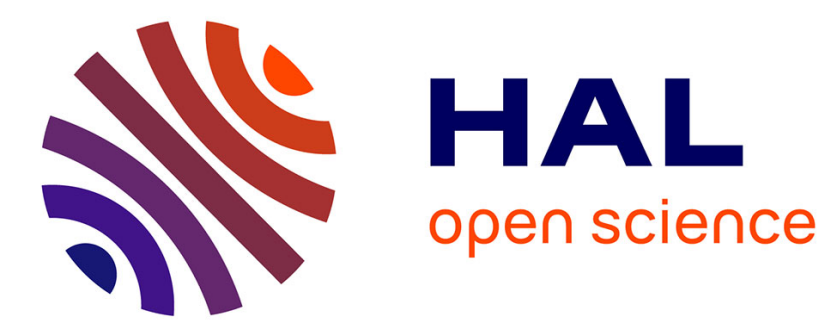

\title{
Organic photovoltaics: a chemical approach
}

Juan Luis Delgado, Pierre-Antoine Bouit, Salvatore Filippone, Mª Ángeles Herranz, Nazario Martín

\section{To cite this version:}

Juan Luis Delgado, Pierre-Antoine Bouit, Salvatore Filippone, Mª Ángeles Herranz, Nazario Martín. Organic photovoltaics: a chemical approach. Journal of the Chemical Society, Chemical Communications, 2010, 46, pp.4853-4865. 10.1039/C003088K . hal-01090389

\section{HAL Id: hal-01090389 https://hal-univ-rennes1.archives-ouvertes.fr/hal-01090389}

Submitted on 4 Dec 2014

HAL is a multi-disciplinary open access archive for the deposit and dissemination of scientific research documents, whether they are published or not. The documents may come from teaching and research institutions in France or abroad, or from public or private research centers.
L'archive ouverte pluridisciplinaire HAL, est destinée au dépôt et à la diffusion de documents scientifiques de niveau recherche, publiés ou non, émanant des établissements d'enseignement et de recherche français ou étrangers, des laboratoires publics ou privés. 


\title{
Organic Photovoltaics: A Chemical Approach
}

\author{
Juan Luis Delgado, ${ }^{a, b}$ Pierre-Antoine Bouit, ${ }^{\mathrm{b}}$ Salvatore Filippone, ${ }^{\mathrm{a}} \mathrm{M}^{\mathrm{a}}$ Ángeles Herranz, ${ }^{\mathrm{a}}$ and Nazario \\ Martín,*a,b
}

\begin{abstract}
5 Abstract. The design of new organic functional molecules able to harvest sun light and efficiently undergo photon to current energy conversion processes is at the forefront of chemical challenges. In this review the fundamental contribution of chemistry to the multidisciplinary field of organic photovoltaics is presented in a systematic way through the wide variety of organic compounds synthesized to be successfully used in photovoltaic devices.
\end{abstract}

10 Juan Luis Delgado obtained his PhD (2004) from the Universidad de Castilla-la Mancha under the supervision of Prof. Fernando Langa. Afterwards he joined the group of Prof. JeanFrançois Nierengarten, initially at the ECPM-CNRS (Strasbourg, France) and later on at the LCC (CNRS, Toulouse, France), 15 where he worked as a postdoctoral fellow (2005-2006). He then joined the group of Prof. Nazario Martín in December 2006 as a "Juan de la Cierva" postdoctoral fellow. Currently he holds a "Ramón y Cajal" research contract at IMDEA-Nanociencia, where he is focused on the design of new carbon-based energy 20 storing materials for the development of efficient organic photovoltaic devices.

Pierre-Antoine Bouit was graduated in 2005 from the Ecole Nationale Supérieure de Paris (ENSCP, France). He obtained a ${ }_{25} \mathrm{PhD}$ in 2008 at the Ecole Normale Supérieure de Lyon (ENSLyon, France) under the supervision of Dr O. Maury and Dr C. Andraud on the synthesis of near infrared absorbing dyes for nonlinear optics. Then he joined the group of Prof. Nazario Martín at UCM in 2008 as IMDEA post-doc. His current research 30 interests are the synthesis of exTTF and [60]fullerene based materials for the preparation of Photovoltaic devices (Bulk HeteroJunctions and Dyes Sensitized Solar Cells).

Salvatore Filippone is a Ramón y Cajal researcher at ${ }_{35}$ Complutense University. He obtained his $\mathrm{PhD}$ degree at University of Pavia (Italy). His thesis was conducted under the supervision of Prof. Faita on metal catalyzed asymmetric synthesis. In 2000, he moved to Ecole Normale Superieure of Paris for a postdoctoral fellowship on biological evaluation of 40 fullerene derivatives, working with Prof. Rassat and Prof. Bensasson. Since April 2002, he joined Prof. Nazario Martín's group, working mainly on new chemical reactivity of fullerenes involving asymmetric approaches, and molecular wires.

45

$\mathbf{M}^{\mathrm{a}}$ Ángeles Herranz gained a $\mathrm{PhD}$ from Complutense University of Madrid (UCM) in 2001. Then she moved to the USA to work as a postdoctoral researcher, first at the University of Miami (2001) and then at Clemson University (2002-2004). In ${ }_{50}$ March 2004 she joined the group of Prof. Nazario Martín at UCM, initially holding a Ramón y Cajal research associate position and since 2007 as Assistant Professor. She became an Associate Professor of Chemistry in 2009. Her current research interests primarily focuses on the chemistry and electronic 55 properties of carbon nanostructures and in single-molecule electronics.

Nazario Martín is full professor of Chemistry at Complutense University and vice-Director of IMDEA-Nanoscience Institute.
${ }_{60}$ His research interests span a range of targets with emphasis on the chemistry of carbon nanostructures in the context of electron transfer processes, photovoltaic applications and nanoscience. He is a member of the Editorial Board of Chemical Communications, a member of the international advisory board of The Journal of ${ }_{65}$ Organic Chemistry and ChemSusChem, and the Regional Editor for Europe of Fullerenes, Nanotubes and Carbon Nanostructures. He is a member of the Real Academia de Doctores de España, a fellow of The Royal Society of Chemistry and the President of the Spanish Royal Society of Chemistry. 70

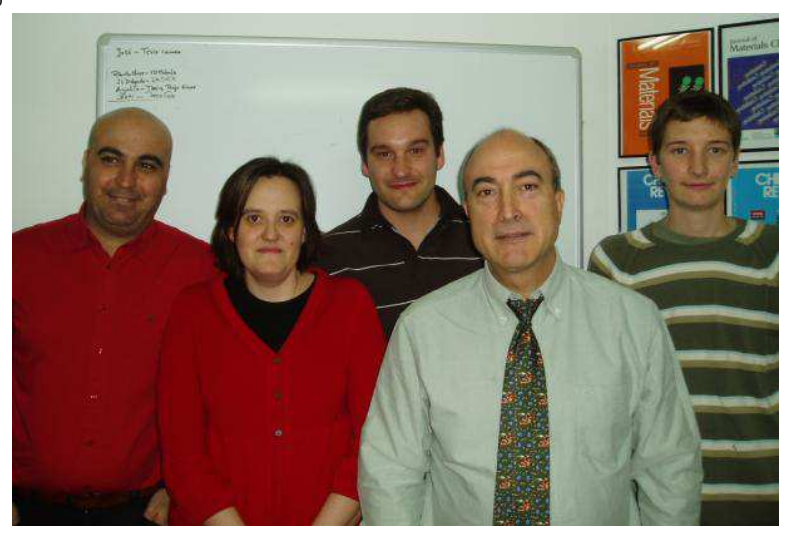

\section{Introduction}

Energy is currently the most important problem facing mankind. The "fire age" in which our civilization has been based from the 75 very beginning is approaching to its end. Human being has been burning a wide variety of materials since earlier times and with the advent of carbon-based fossil fuels in the last two centuries, its combustion has become nowadays a major problem due to the huge amounts of carbon dioxide emissions produced all over the 80 world. Because of the resulting pollution, global warming and degradation of the planet, a new era based on non contaminating renewable energies is currently a priority. In this regard, the Sun considered as a giant nuclear fussion reactor represents the most powerful source of energy available in our Solar system and, 85 therefore, its use for providing energy to our planet is among the most important challenges nowadays in science. Actually, the energy received from Sun, calculated in 120,000 TW (5\% ultraviolet; $43 \%$ visible and $52 \%$ infrared), surpass in several thousands that consumed in the planet along a year. ${ }^{1}$

90 Photovoltaic (PV) solar cells is currently a hot topic in science 
and since the former silicon-based device prepared by Chapin in 1954 exhibiting an efficiency around $6 \%,{ }^{2}$ different semiconducting materials (inorganic, organic, molecular, polymeric, hybrids, quantum dots, etc) have been used for 5 transforming sun light into chemical energy. Among them, photo- and electro-active organic materials are promising due to key advantages such as the possibility of processing directly from solution, thus affording lighter, cheaper and flexible all-organic PV devices. Actually, these organic 10 systems have received a lot of attention and a variety of excellent reviews and special issues have recently been published. ${ }^{3}$ They are mainly focussing on the race to increase efficiency as well as on those aspects mostly related with the understanding of those essential optical and electronic 15 processes able to transform photon energy into electricity, thus providing a general overview on the state of the art in organic PV solar cells. ${ }^{4}$

Therefore, the aim of this review is to emphasize the contribution of chemistry to this field by covering those 20 aspects related with the nature and properties of those type of compounds used to construct "all-organic" PV devices. Furthermore, the systematic organization of those compounds used for different purposes and tasks in organic solar cells should help to the chemical community to think about and to 25 rationalize further alternative compounds which, eventually, result in a better performance of the PV devices.

Thus, this is not a comprehensive review on the chemistry of the so-called "all-organic" or "excitonic" (absorption of light results in the formation of excitons, basically a neutral 30 electron-hole pair) solar cells but, on the contrary, a presentation of the most relevant chemical compounds which currently define the different classes of "all-organic" PV cells. Thus, we have organized this review in four main parts: i) Basic processes in organic solar cells; ii) Bulk-heterojunction 35 plastic solar cells based on semiconducting $\pi$-conjugated polymers and fullerenes; iii) Molecular bulk-heterojunction solar cells based on $\pi$-conjugated oligomers or dyes and fullerenes; iv) Other carbon nanostructures, namely endohedral fullerenes and carbon nanotubes (CNTs). Actually, 40 the presence of pristine fullerenes $\left(\mathrm{C}_{60}\right.$ and $\left.\mathrm{C}_{70}\right)$, or most commonly a fullerene derivative (namely PCBM: 1-(3methoxycarbonyl)propyl-1-phenyl[6,6]C $\left.\mathrm{C}_{61}\right)$, is a common feature in sections ii) and iii). Therefore, it is not surprising the recent interest in other available related carbon 45 nanostructures such as endofullerenes and CNTs, which is covered in iv).

\section{i) Basic Processes in Organic Solar Cells}

${ }_{50}$ Organic solar cells are constituted by semiconducting organic materials formed by contacting electron donor and acceptor compounds ( $\mathrm{p} / \mathrm{n}$ type). A further improvement in the construction of organic photovoltaic devices (OPV) consists on the realization of interpenetrated networks of the donor and 55 acceptor materials. In such bulk heterojunction (BHJ) solar cells, the dramatic increasing of contacting area between D/A materials leads to a significant increasing of the number of generated excitons as well as their dissociation into free charge carriers and hence on the power conversion efficiency 60 (Figure 1).

Transformation of solar energy into electricity occurs through a series of optical and electronic processes which basically involves: i) optical absorption of sun light and formation of the exciton; ii) exciton migration to the donor-acceptor 65 interface; iii) exciton dissociation into charges (electron and holes), and iv) charge transport and collection at the electrodes. All these steps are not totally understood at present and a number of research groups are currently dedicated to unravel essential aspects in the search for better energy 70 transformation efficiencies. ${ }^{5}$ In contrast to inorganic semiconductors which upon light excitation form free electron and hole carriers, organic compounds form excitons whose dissociation into free carriers is not straightforward. Due to their low dielectric constants, it requires reaching the donor75 acceptor interface to dissociate into free charges. The driving force for this exciton dissociation being provided by the energy difference between the molecular orbitals of the donor and acceptor.

The transport of the thus generated free charges toward the 80 electrodes represents another important issue. Organic materials tipically show charge carrier mobilities significantly lower (around $10^{-5}$ to $1 \mathrm{~cm}^{2} \mathrm{~V}^{-1} \mathrm{~s}^{-1}$ ranging from amorphous to crystalline materials) than those of inorganic semiconductors (around $10^{2}-10^{3} \mathrm{~cm}^{2} \mathrm{~V}^{-1} \mathrm{~s}^{-1}$ ). Since charge carriers mobility is 85 strongly dependent on the molecular organization of the material, in order to achieve better efficiencies, a good control on the morphology of the donor-acceptor materials at a nanometer scale is necessary. Furthermore, an efficient charge carriers mobility is essential to prevent charge recombination 90 (geminal or bimolecular) processes which result in lower energy conversion efficiencies.

In summary, an appropriate choice of the donor and acceptor materials is critical to ensure a good match between them in terms of optical, electronic and morphological properties, 95 which eventually determine the effective photocurrent and performance of the PV device. Therefore, the rational design of new materials able to improve some specific demands within the PV device is critical for the successful development of competitive solar cells. In the following sections, we will 100 discuss those materials mainly used in the preparation of "allorganic" solar cells according to their chemical nature and composition.

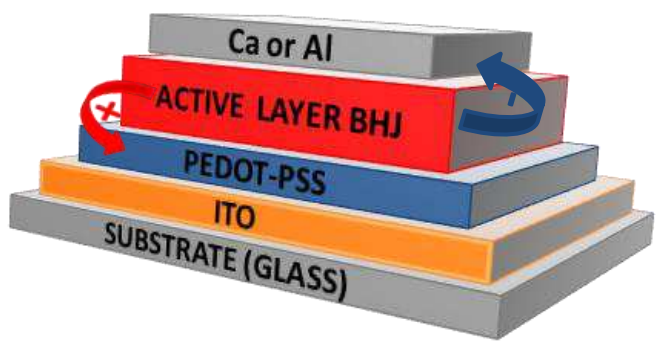

${ }_{105}$ Figure 1. Basic chemical components for a typical Organic Photovoltaic (OPV) Solar Cell.

\section{ii) Bulk-heterojunction "plastic" solar cells}


The term "plastic solar cells" has been coined for those photovoltaic devices using polymers in their constitution. Thus, although a variety of donor and acceptor polymers have 5 previously been used for constructing PV devices, the highest efficiencies have been achieved by mixing electron donor polymers with fullerenes as acceptors. Polymer:fullerene (BHJ) based solar cells ${ }^{6}$, a are considered suitable candidates to obtain low-cost renewable energy from a large-area, 10 flexible, plastic material.

Fullerenes and their derivatives possess important electronic properties like small reorganization energy, high electron affinity, ability to transport charge and stability, that makes them (see below) one of the best candidates to act as electron 15 acceptor components in BHJ photovoltaic PV devices. ${ }^{4,7}$ On the other hand, MDMO-PPV \{poly[2-methoxy-5-(3',7'dimethyloctyloxy)]-1,4-phenylenevinylene $\}$ and $\mathrm{P} 3 \mathrm{HT}$ [poly(3-hexylthiophene-2,5-diyl)] have been by far the most studied $\pi$-conjugated polymers as donor components in $\mathrm{BHJ}$ 20 devices. Actually, both polymers have thoroughly been studied from a morphological and electronic standpoint to form $\mathrm{BHJ}$ devices by mixing with fullerene derivatives, namely PCBM (19, Figure 4). In fact, the best fullerene/polymer combination has been obtained with

${ }_{25} \mathrm{PCBM} / \mathrm{P} 3 \mathrm{HT}$ (regioregular) mixtures, reaching energy conversion efficiencies in the range of $5 \% .^{8}$

In the following, we will briefly describe the most relevant achievements both in the chemistry of polymers as well as on the fullerene chemical modifications for PV purposes.

\section{0 a) Polymers for BHJ Photovoltaics}

Polymers endowed with fullerenes is a broad interdisciplinary field of interest for a variety of purposes. ${ }^{9}$ However, photovoltaics are among the most realistic applications for polymer/fullerene blends.

35 The chemistry of $\pi$-conjugated polymers has been focused on tuning their energy (HOMO and LUMO) levels in order to have a good control on the band gap of the polymer. This is a key issue to modulate the light harvesting properties of the polymer [low band gap polymers (lower than $1.5 \mathrm{eV}$ ) absorb 40 in the visible region] as well as the right energy match with the acceptor moiety which, eventually, controls the open circuit voltage (Voc) values, and hence the cell power conversion efficiency.

Since $\pi$-conjugated polymers constitute an specific field by 45 their own right, we will discuss the trends currently followed in polymer chemistry to improve the performance of those "classical" MDMO-PPV and P3HT. Some of the most relevant polymers synthesized so far are shown in Figure 2. All of them involve the use of alternating donor and acceptor 50 moieties within the polymer backbone since they allow a fine tune of the band gap of the polymer, as well as an improvement of planarity and hence of the mobility of the charge carriers. Thus, a variety of soluble electroactive carboand heterocycle derivatives such as fluorene, thiophene, 55 cyclopentadithiophene and carbazole have been used as electron rich units, whereas benzothiadiazole and thienopyrazine have recently been used as the electron poor units.
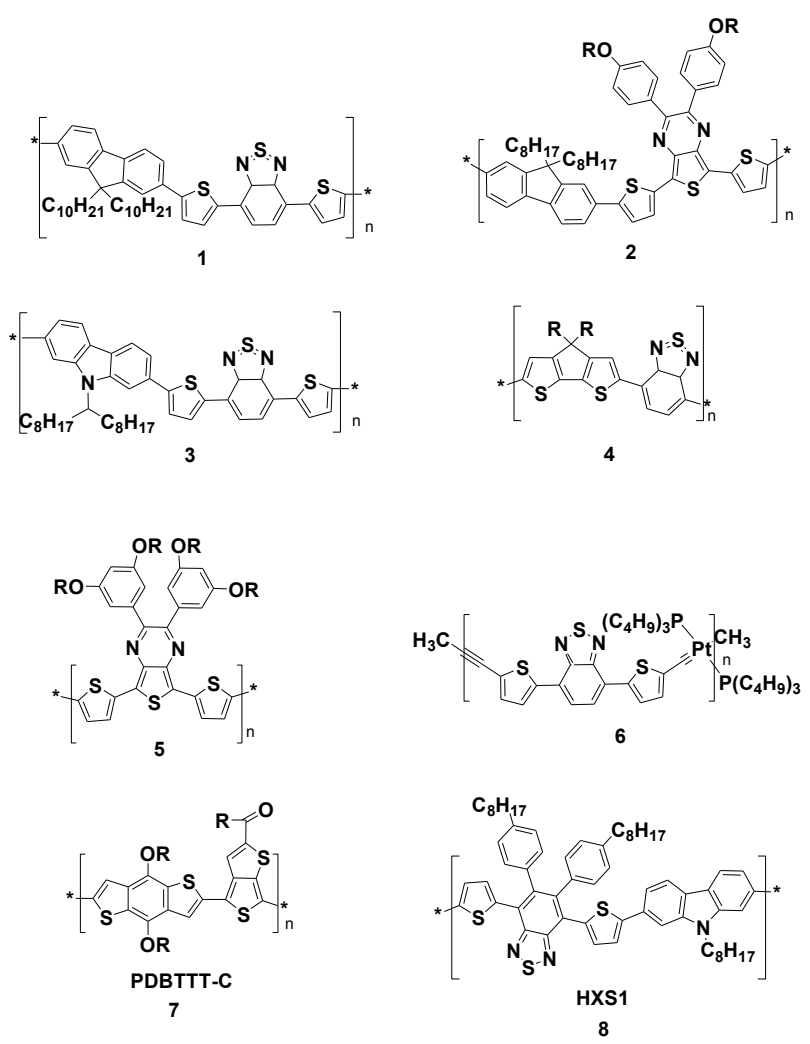

R=2-ethylhexyl

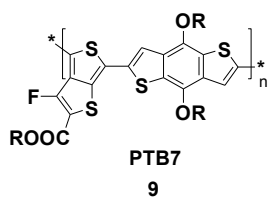

60 Figure 2. Representative polymers for PV devices: 1)poly $[9,9$-didecanefluorene-alt-(bisthienylene) benzothiadiazole $],{ }^{10}$ 2) APFO-Green $5,^{11}$ 3) poly[N-9'heptadecanyl-2,7-carbazole-alt-5,5-(4',7'di-2-thienyl-2',1',3'benzothiadiazole)], ${ }^{12}$ 4) poly[2,6-(4,4-bis-(2-ethylhexyl)-4H65 cyclopenta[2,1-b;3,4-b2]-dithiophene)-alt-4,7-(2,1,3-

benzothiadiazole $){ }^{13} \quad$ 5) poly $\{5,7-d i-2-t h i e n y l-2,3-b i s(3,5-$ di(2-ethylhexyloxy)phenyl)thieno[3,4-b]pyrazine $\},{ }^{14}$ 6) platinum(II) polyyne polymer, ${ }^{15}$ 7)PDBTTT-C, ${ }^{16}$ 8), HXS1 ${ }^{17}$ 9) PTB $^{18}$

70

Among the different electron donor polymers prepared so far, we want to focus on a variety of polyfluorene copolymers prepared by Andersson et al. known as APFO (alternating polyfluorene copolymers) (2), which have allowed a good 75 control on the band gap, covering the solar spectrum up to $1000 \mathrm{~nm}$. Power conversion efficiencies over than $4 \%$ have been demonstrated with APFOs in blends with PCBM. ${ }^{19}$

Typically, $\pi$-conjugated polymers are endowed with flexible lateral chains to improve their solubility. However, in many cases 80 the side chains prevent the polymer backbones from close packing. Recently, a planar polymer conformation has been achieved in polymer poly(2-(5-(5,6-bis(octyloxy)-4-(thiophen-2yl)benzo[c][1,2,5]thiadiazol-7-yl)thiophen-2-yl)-9-octyl-9H 
carbazole, HXS-1) bearing two octyloxy chains on the benzothiazole ring and an octyl chain on the carbazole ring. The synthesis of HXS-1 is shown in Scheme 1 to illustrate the synthetic strategy followed for the preparation of this kind of 5 polymers. Thus, the coupling reaction of 4,7-dibromo-5,6bis(octyloxy)benzo-2,1,3-thiadiazole (10) with 4,4,5,5tetramethyl-2-(thiophen-2-yl)-1,3,2-dioxaborolane (11) using $\mathrm{Pd}\left(\mathrm{PPh}_{3}\right)_{4}$ as the catalyst precursor and aqueous $\mathrm{NaHCO}_{3}$, and THF as solvent, led to compound $\mathbf{1 2}$ in moderate yield.

10 Bromination of $\mathbf{1 2}$ with $\mathrm{N}$-bromosuccinimide afforded $\mathbf{1 3}$ whose further Suzuki-Miyaura polycondensation with 2,7-bis(4,4,5,5tetramethyl-1,3,2-dioxaborolan-2-yl)-9-octyl-9H-carbazole (14) using $\mathrm{Pd}\left(\mathrm{PPh}_{3}\right)_{4}$ as the catalyst precursor in a biphasic mixture of THF-toluene (5:1)/aqueous $\mathrm{NaHCO}_{3}$ formed polymer HXS1 as a 15 black solid in good yield. ${ }^{18}$

Semiconducting polymers based on alternating thieno[3,4b]thiophene and benzodithiophene units such as $\mathbf{7}$ and $\mathbf{9}$ show an excellent photovoltaic behaviour. The stabilization of the quinoid structure from the thieno[3,4-b]thiophene moiety leads to 20 remarkable low band gap polymers (around $1.6 \mathrm{eV}$ ). A further optimization has been achieved with the new PTB7 in which the presence of the fluorine atom leads to a lower HOMO level, thus enhancing the $\mathrm{V}_{o c}$ parameter. With an average molecular weight around $97.5 \mathrm{KDa}$ and a polydispersity index of 2.1, this soluble 25 polymer exhibits a strong absorption from 550 to $750 \mathrm{~nm}$. Interestingly, by blending this polymer with $\mathrm{PC}_{71} \mathrm{BM}$, which nicely complements the absorption in the visible range, has allowed preparing a PV device exhibiting an energy conversion efficiency of $7.40 \%$. This value represents the highest efficiency 30 reported so far for a polymeric solar cell. ${ }^{18}$
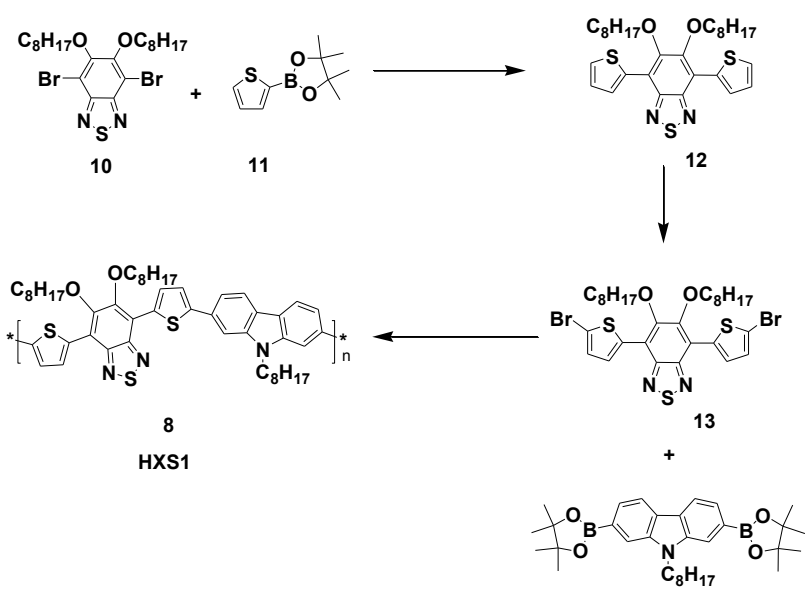

Scheme 1. Synthesis of polymer HXS1.

14

Since the development of new $\pi$-conjugated donor polymers 35 for improving the efficiency in BHJ photovoltaic devices is currently a broad and very active field, out of the scope of this general presentation, for further details the reader is referred to some of the excellent monographs available in the literature. $^{20}$

\section{${ }_{40}$ b) Chemically Modified Fullerenes for BHJ Photovoltaics}

The most widely used configuration of polymer solar cells is based on the use of a fullerene derivatives as acceptor component. Indeed, fullerenes have been demonstrated to be the ideal acceptor because of their singular electronic and 45 geometrical properties and for the ability of their chemically functionalized derivatives to form a bicontinous phase network with $\pi$-conjugated polymers acting as electron conducting ( $n$ type) material.

A variety of chemically modified fullerenes were initially 50 synthesized for blending with semiconducting polymers (namely PPV derivatives) and to prepare photovoltaic devices. These fullerene derivatives were covalently linked to different chemical species such as electron acceptors, ${ }^{21}$ electron donors, ${ }^{22} \pi$-conjugated oligomers, ${ }^{23}$ dendrimers, ${ }^{24}$ etc. (Figure $\left.{ }_{55} 3\right)$. However, in general, the obtained blends resulted in PV devices exhibiting low energy conversion efficiencies. ${ }^{25}$

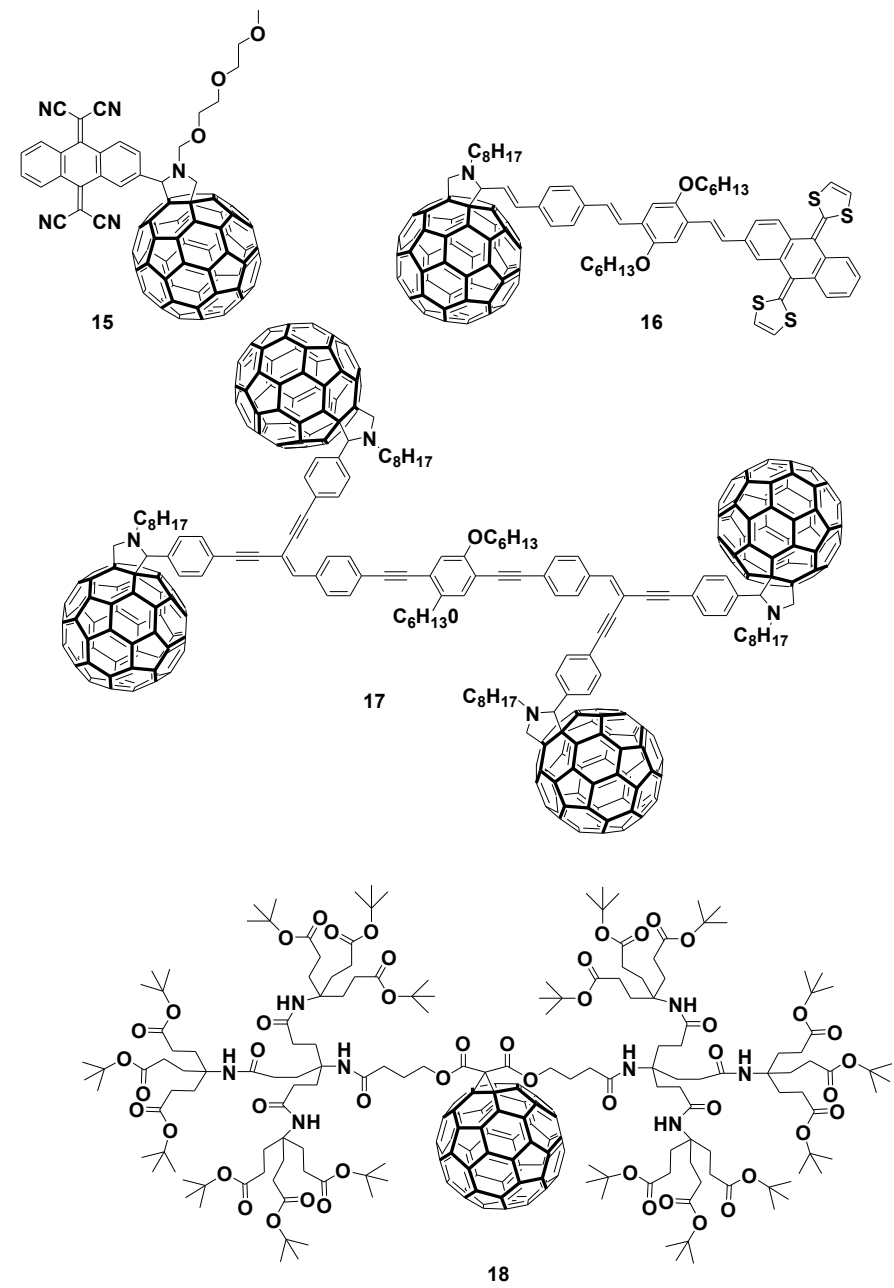

Figure 3. Some examples of modified fullerenes bearing ${ }_{60}$ different organic addends (15-18) used to prepare photovoltaic devices. .

The best known and most widely used fullerene derivative as acceptor for $\mathrm{PV}$ devices is $[6,6]$-phenyl- $\mathrm{C}_{61}$ butyric acid 65 methyl ester 19 (PCBM), firstly prepared by Hummelen and Wudl in $1995 .^{26}$ Since its first reported application in solar cells, ${ }^{27}$ it has been by far the most widely used fullerene, 
being considered as a benchmark material for testing new devices.

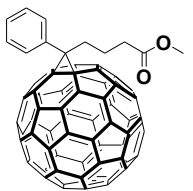

19 (РCBM)

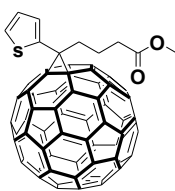

20 ([60]ThCBM)

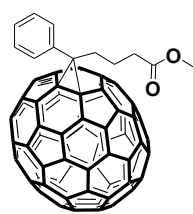

$21\left(\mathrm{PC}_{71} \mathrm{BM}\right)$
${ }_{5}$ Figure 4. PCBM and other representative PCBM analogues involving a thienyl group ([60]ThCBM) or a [70]fullerene $\left(\mathrm{PC}_{71} \mathrm{BM}\right)$.

This has led to the synthesis of many other PCBM analogues $10(\mathbf{2 0 , 2 1})^{28}$ in an attempt to increase the efficiencies of the cells by improving the processability, the stability or PV parameters such as the open circuit voltage (Voc) by rising the LUMO energies of the fullerene acceptor (Figure 4).

In this regard, only small shifts $(<100 \mathrm{meV})$ of the LUMO 15 level have been obtained by attaching a single substituent on the fullerene sphere, even by using electron-donating groups. In contrast, significantly higher Voc values have been achieved through the polyaddition of organic addends to the fullerene cage $(\sim 100 \mathrm{mV}$ raising the LUMO per saturated 20 double bond). Recently, an externally verified powerconversion efficiency of $4.5 \%$ has been reported by Hummelen et al. employing a regioisomeric mixture of PCBM bisadducts as result of an enhanced open-circuit voltage, while maintaining a high short-circuit current $\left(J_{s c}\right)$ and fill 25 factor $(\mathrm{FF})$ values. ${ }^{29}$

The cyclopropanation reaction to superior fullerenes to form PCBM analogues is more complex than for $\mathrm{C}_{60}$. Indeed, the less symmetry and the presence of more than one reactive double bond is often responsible for the formation of 30 regioisomeric mixtures. Nevertheless, the loss of symmetry of $\mathrm{C}_{70}$ induces a stronger absorption, even in the visible region. As a result, $\mathrm{PC}_{71} \mathrm{BM}^{30}$ is considered a suitable candidate for more efficient polymer solar devices. Moreover, such devices performed the highest verified efficiency determined so far in

35 a BHJ solar cell, with an internal quantum efficiency approaching $100 \% .^{31}$ Analogously, $\mathrm{PC}_{84} \mathrm{BM},{ }^{32}$ has been obtained as a mixture of three major isomers. The stronger electron affinity and the diminished solubility gave rise, however, to poor power conversion efficiencies.

40 Although the PCBMs are the acceptor that best performances guarantees to the moment, it does not mean that they are necessarily the optimum fullerene derivatives. Therefore, a variety of other fullerene derivatives ${ }^{33}$ have been synthesized in order to improve the device efficiency or to achieve a better

45 understanding on the dependence of the cell parameters from the structure of the acceptor.

Among the different modified fullerenes prepared so far, diphenylmethanofullerene 22 (DPM12) prepared by Martín et al. is another successful type of methanofullerene endowed 50 with two alkyl chains to drastically improve the solubility of the acceptor in the blend and reaching efficiencies in the range of $3 \%$ (Figure 5). Although the LUMO energy level for
DPM12 is the same as that for PCBM, an increase for the Voc of $100 \mathrm{mV}$ for the DPM12 over PCBM has been observed. ${ }^{34,35}$

${ }_{55}$ This is currently an important issue for improving the design of future fullerene-based acceptors.

Devices based on dihydronaphthylfullerene benzyl alcohol benzoic ester (23) synthesized by Fréchet et al. reported one of the highest power conversion efficiency (PCE) (up to 4,5\%) ${ }_{60}$ for a non PCBM based polymer-fullerene solar cell. ${ }^{36}$

An alternative molecular approach to control both the length scale of polymer/fullerene phase segregation and the electron mobility in the fullerene network is based on the employ of a self assembly fullerene shuttlecock derivative (24), able to 65 form one-dimensional wirelike domain within the active layer. $^{37}$

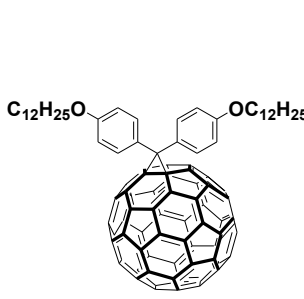

22 (DPM)

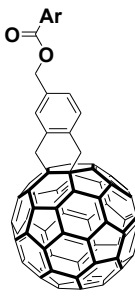

23

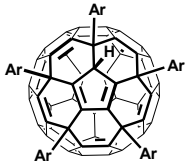

24
Figure 5. Different modified fullerenes used as successful 70 acceptors for PV devices

Although fullerene dimers are known to exhibit low solubilities, ${ }^{38}$ recently a series of soluble homo (25: $\mathrm{C}_{60}-\mathrm{C}_{60}$ and 26: $\left.\mathrm{C}_{70}-\mathrm{C}_{70}\right)$ and heterodimers $\left(27: \mathrm{C}_{60}-\mathrm{C}_{70}\right)$ formed from ${ }_{75} \mathrm{C}_{60}$ and $\mathrm{C}_{70}$ derivatives have been prepared and explored as less-known acceptors for PV devices. ${ }^{39}$ The synthesis of these pyrrolidino-pyrazolino fullerene dimers has been carried out in a straightforward manner from the formyl-containing pyrazolino[60] or [70]fullerene, ${ }^{40}$ which is used as the 80 aldehyde component in the subsequent pyrrolidine formation by 1,3-dipolar cycloaddition of the respective azomethyne ylide with the fullerene. ${ }^{41}$ As expected, [70]fullerene dimers showed better absorption in the visible spectrum than the analogues of [60]fullerene. Interestingly, non optimized BHJ

85 solar cells formed by blending with P3HT exhibited quantum conversion efficiencies of $37 \%$, with a PCE of 1,0\% (Figure $6)$. 


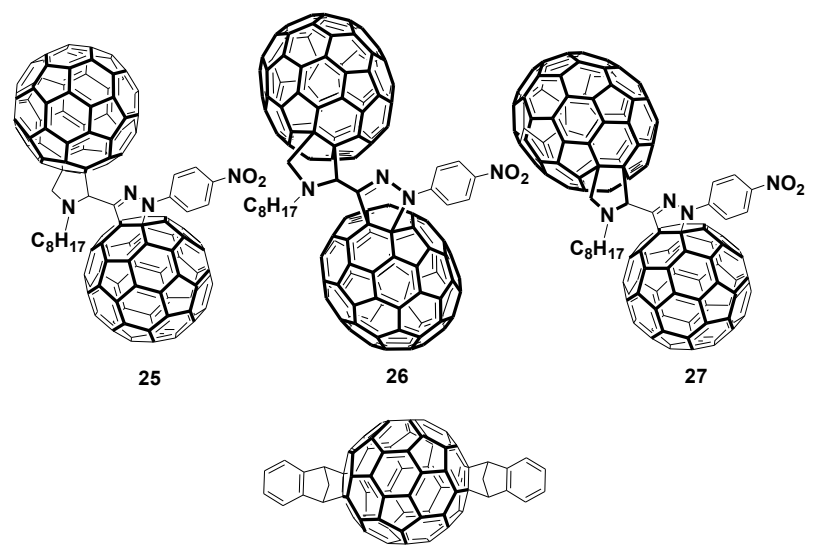

28

Figure 6. Homo- and hetero-dimers of $\mathrm{C}_{60}$ and $\mathrm{C}_{70}$ (25-27) and bis-cycloadduct $\mathbf{2 8}$ bearing two indene units.

A remarkable bis-adduct fullerene derivative formed by two 5 indene units covalently connected to the fullerene sphere of $\mathrm{C}_{60}$ (28) has recently been reported by $\mathrm{Hou}$ and $\mathrm{Li}^{42}$ Interestingly, the presence of two aryl groups improves the visible absorption compared to the parent PCBM, as well as its solubility (> $90 \mathrm{mg} / \mathrm{ml}$ in chloroform) and the LUMO 10 energy level, which is $0.17 \mathrm{eV}$ higher than PCBM. Surprisingly, PV devices formed with P3HT as semiconducting polymer revealed PCE values of $5.44 \%$ under illumination of $\mathrm{AM} 1.5,100 \mathrm{~mW} / \mathrm{cm}^{2}$, thus surpassing to PCBM which afforded an efficiency of $3.88 \%$ under the same 15 experimental conditions.

A major drawback in the synthesis of bis-adducts of fullerenes is that the products formed are constituted by a mixture of regioisomers which are not separated because of the experimental difficulties. This fact, however, does not seem 20 to have a strong influence on the PV parameters and power conversion efficiencies. Nevertheless, from a chemical viewpoint, the synthesis of isomerically pure bis-adducts and multiadducts of fullerenes is still an open question which should be properly addressed by the chemical community.

25 Although some of the fullerene derivatives prepared so far exhibit good performances in PV devices, the synthesis of new fullerene derivatives with stronger visible absorption and higher LUMO energy levels than PCBM is currently a challenge for all those chemists engaged in the chemical 30 modification of fullerenes for PV applications.

\section{c) Double-Cable Approach for BHJ Photovoltaics}

This strategy is based on the appendage of the acceptor moiety to the $\pi$-conjugated polymeric skeleton with the aim to maximize the interface between the two active components, 35 thus preventing the phase separation between them. At the same time, such approach is expected to promote an efficient charge transport to the electrods through a nanoscale homogeneous distrubution of the domains of the donor and the acceptor in the blend.

40 The first example of a PV cell prepared by using the doublecable approach was carried out by spin coating from poly $(p$ phenylenevinylene) and poly( $p$-phenyleneethynylene) covalently connected to methanofullerene units. Photovoltaic parameters $\left(\mathrm{Voc}=0.83 \mathrm{~V} ; \mathrm{Jsc}=0.42 \mathrm{mAcm}^{-2} ; \mathrm{FF}=0.29\right.$ 45 under AM1.5 conditions) resulted to be quite promising. ${ }^{43}$

Interestingly, the realization of effective double-cable polymers brings the $\mathrm{p} / \mathrm{n}$ heterojunction at the molecular level, thus allowing a better control from a chemical viewpoint. ${ }^{44}$ However, to date, and despite the beauty of this chemical 50 design, double-cable polymers ${ }^{45,9 b, 11 \mathrm{c}}$ have yielded poor energy conversion efficiencies. One of the reasons to account for this finding has been the low fullerene loading of the material. Therefore, new polymers have been synthesized such as PTF (29) or PBTC-F (30) with a higher fullerene 55 content (up to 63 wt \%) (Figure 7). Other studies involving polythiophenes followed to this one with slightly better performances and efficiencies around $0.60 \%{ }^{46}$

An interesting alternative approach is based on the use of welldefined rod-coil block copolymers consisting of P3HT donor and ${ }_{60} \mathrm{C}_{60}$ acceptor chromophores (P3HT- $\left.\boldsymbol{b}-\mathbf{P}\left(\mathbf{S}_{\boldsymbol{x}} \mathbf{A}_{\boldsymbol{y}}\right)-\mathbf{C}_{\mathbf{6 0}}\right)$ (31) as "surfactant". The control of the interface morphology of the P3HT:PCBM donor-acceptor phase domains within the composite resulted in an improvement of the efficiency with respect to the analogous solar cell fabricated without the 65 "surfactant". 47
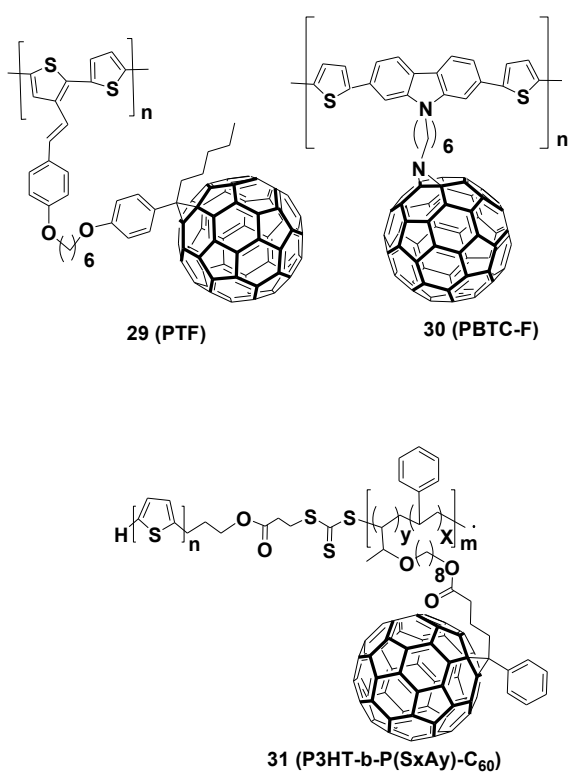

Figure 7. Some representative examples of fullerene70 containing polymers used fo the double-cable approach.

\section{iii) Molecular Bulk-Heterojuntions}

Despite the outstanding results obtained from BHJ solar cells formed from fullerenes and polymers, the use of commercially available P3HT displays a number of troubles associated to its 75 synthesis, purification, and inherent electronic properties. ${ }^{48}$ Factors such as polydispersity, regioregularity and molecular weight have a strong influence on the final performance of the photovoltaic device, which indicates that the control over P3HT structure and purity is an important issue for controling 80 organic photovoltaics. Concerning its electronic properties, it has been calculated that P3HT can only absorb $46 \%$ of the 
available solar photons, ${ }^{49}$ owing to a bandgap of $1.90 \mathrm{eV}$ and a relatively narrow absorption band. A promising solution to overcome these limitations could be the use of soluble small conjugated molecules instead of polymers. This strategy 5 would avoid the above mentioned structural problems inherent to polymers, and allow the use of several well-defined small molecules whose electronic properties can be tuned by chemical synthesis, in order to obtain a better photovoltaic performance. Following this approach, in the last years, a 10 number of molecules ${ }^{48}$ such as oligomers, dendrimers, dyes and porphyrines have been used as molecular donors blended with pristine [60]fullerene or [60]fullerene derivatives, in order to prepare new and efficient photovoltaic devices.

a) Conjugated oligomers and dendrimers as donors in $\mathbf{B H J}$ ${ }_{15} \mathbf{P V}$ devices

The synthesis and study of new organic monodisperse $\pi$ conjugated oligomers is a hot topic in photovoltaics. ${ }^{50}$ Oligothiophenes are among the most promising oligomers, due to their exceptional electronic properties and easy tuning 20 of their properties by introducing functional substituents. Several substitued oligothiophenes have been described and studied for organic photovoltaics. However, most of them show a planar geometry, which tends to aggregate due to $\pi-\pi$ stacking interactions. Sun et $a l,{ }^{51}$ described recently the 25 preparation of new X-shaped oligothipohenes (32-35) as electron donors in BHJ-PV devices blended with PCBM (Figure 8). The authors observed that both the open circuit voltage $\left(V_{O C}\right)$ and the short circuit current $\left(J_{S C}\right)$ are highly dependent on the oligothiophene chain length. While 30 increasing the number of oligothiophene rings, the absorption was red-shifted and broadened, therefore the light harvesting properties and the PCE increase from $0.008 \%$ to $0.8 \%$.
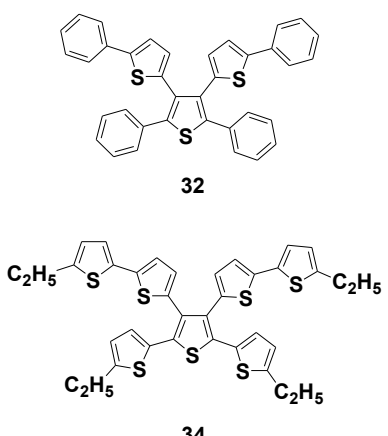

34
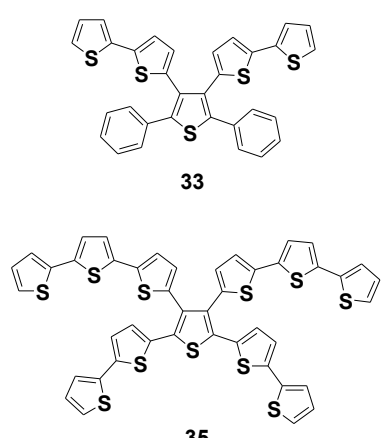

35
Figure 8. Chemical structures of four X-shaped oligothiophenes.

${ }_{35}$ Other interesting oligothiophene-based compound, was recently described by Tamayo et al, ${ }^{52}$ namely oligothiophene diketopyrrolo-pyrrole (36) (SMDPPEH, Figure 9). This appealing oligothiophene is a low bandgap well-defined molecule that displays intense absorption bands at 650 and $40720 \mathrm{~nm}$. Blends of this material and $\mathrm{PC}_{71} \mathrm{BM}$ were prepared in different ratios and the results indicated the highest efficiency described so far for a molecular bulk heterojunction (PCE of 3 $\%$ ) being $0.75 \mathrm{~V}$ the $V_{\mathrm{OC}}$ and 9.2 the $J_{\mathrm{SC}}$. Interestingly, the presence of the ethyl-hexyl groups increment the solubility 45 and procesability and, as a consequence, no microscale phase segregation was observed in the films

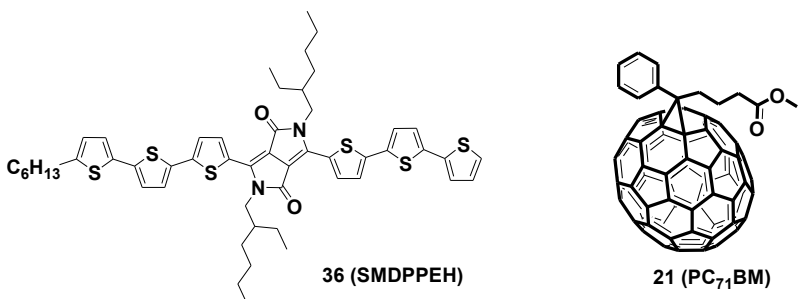

Figure 9: Chemical structures of SMDPPEH and $\mathrm{C}_{71}-\mathrm{PCBM}$

On the other hand, conjugated dendrimers constitute a new 50 kind of well-defined molecular materials with monodisperse structures which are highly controllable due to precise synthetic approaches. In this context Ma et al, ${ }^{53}$ have reported on the photovoltaic properties of BHJ-PV devices prepared with blends of PCBM and various generations of dendritic 55 oligothiopenes (DOTs) bearing from 9 to 90 thiophene units (Figure 10). Owing to the lower HOMO levels of the DOTs, the devices showed remarkable $V_{O C}$ values $(0.93-1.06 \mathrm{~V})$, which are higher by $0.3-0.4 \mathrm{~V}$ in comparison with P3HTPCBM. Other photovoltaic parameters like $J_{S C}$ and external 60 quantum efficiency (EQE), showed a different trend, being their values increased while increassing the size of the DOT. These photovoltaic parameters lead to a maximum power conversion efficiency of $1.72 \%$ for compound 38, which is composed by 42 units of thiophene.

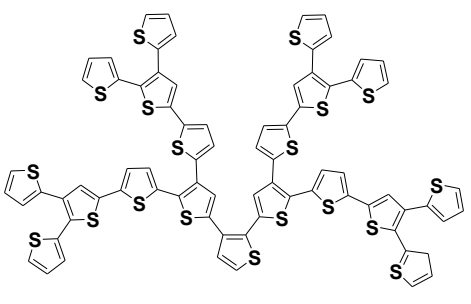

$37(21 \mathrm{~T})$

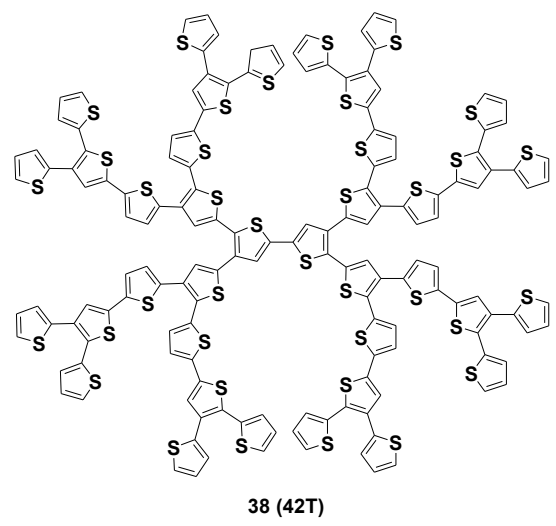

Figure 10. Chemical structures of the DOTs containing 21 and 42 thiophene units.

\section{b) Organic Dyes as donors in BHJ-PV devices}

Following the use of monodisperse and well defined 70 molecules for the preparation of BHJ-PV devices, in the last years a new and interesting approach has emerged in the photovoltaic field. Organic dyes are single molecules which display high absorption extinction coeficients and electronic properties which can be easily tuned by chemical synthesis. 
Roquet et $a l^{54}$ have described the synthesis of triphenylamine (TPA) based compounds (39-41) (Figure 11) bearing several units of dicyanovinylene. Photovoltaic studies on these compounds blended with $\mathrm{C}_{60}$ in bulk and bilayers 5 heterojunctions reveal a high value of $V_{\mathrm{OC}}$ in the BHJ-PV devices due to their high oxidation potential. Owing to an intramolecular charge transfer band from the TPA core to the dicyanovinilene acceptor groups, and to the above mentioned high $V_{O C}$, an improvement of the power conversion efficiency 10 was observed, while the number of dicyanovinylene acceptor units increase in the molecule $(0.49-1.17 \%)$.

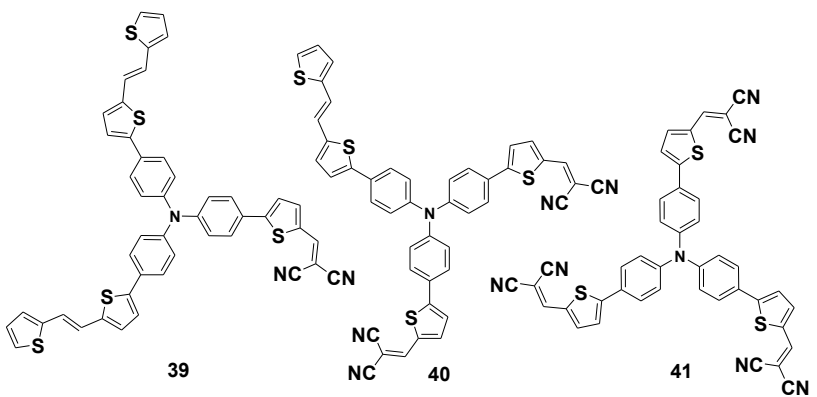

Figure 11. TPA derivatives bearing one or more dicyanovinylene groups.

${ }_{15}$ Kronemberg et al, ${ }^{55}$ have recently described the photovoltaic study of blends of merocyanines and PCBM. These dyes exhibit intense absorption bands ( $\varepsilon$ up to $1.4 \times 10^{-5} \mathrm{M}^{-1} \mathrm{~cm}^{-1}$ ) at different wavelengths in he visible spectral region. For several merocyanine dyes (42) power conversion efficiencies 20 around $1 \%$ were obtained under standard AM 1.5 conditions. Although the best performance was obtained for MD 304 due to a higher $J_{\mathrm{SC}}$ value $\left(6.3 \mathrm{mAcm}^{-2}\right)$ and a $V_{\mathrm{OC}}$ of $0.76 \mathrm{~V}$ which lead to a PCE of $1.74 \%$. In order to harvest light in the NIR region, where almost $50 \%$ of the sunlight power is displayed, ${ }_{25}$ Silvestri et $a l^{56}$ described the synthesis of two new squaraine derivatives $(\mathbf{4 3}, \mathbf{4 4})$ (Figure 12) displaying intense absorption from $700 \mathrm{~nm}$ to $800 \mathrm{~nm}$ in solution. Photovoltaic studies of blends of these dyes with PCBM revealed a power conversion efficiency up to $1.3 \%$. To the best of our knowledge this is the 30 first efficient device prepared using NIR light harvesting molecular dyes. In order to improve the efficiciency of squaraine/PCBM based BHJ, Mayerhöffer et $a l^{57}$ studied the charge carrier mobility of a series of squaraine dyes bearing a dicyanovinyl unit, preparing OFET devices. The authors 35 showed that the most efficient photovoltaic device (PCE= $1.79 \%, \quad J_{S C}=12.6 \mathrm{~mA} \cdot \mathrm{cm}^{-2}$ ) presented good hole-carrier mobility. This remarkable PCE value was attributed to well packed domain of squaraine and PCBM. Besides the introduction of the dicyanovinyl moiety favorably changes the 40 absorption properties of these squaraine dyes, and therefore the capability to harvest solar energy. This study illustrates nicely the importance of tunning both absorption properties and morphology in molecular BHJ cells, as it has previously been shown with polymer-based devices.

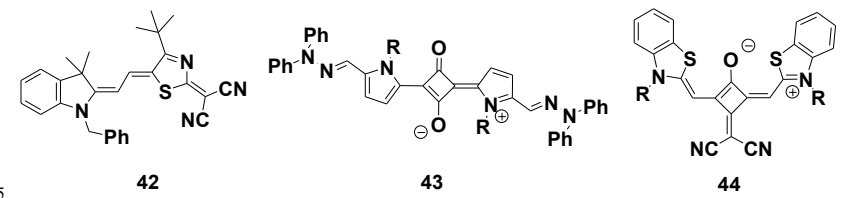

Figure 12. 42) Merocyanine MD 304; 43 and 44) Squaraine derivatives used for preparing PV devices by blending with PCBM.

Borondipyrromethene (BODIPY) dyes $(\mathbf{4 5}, \mathbf{4 6})$ are another 50 kind of organic dye widely used for their outsdanding absorption and fluorescence properties in the visible range. Rousseau et $a l^{58}$ took advantage of the ease of chemical modification on the bodipy core to tune the optical properties of the dyes and reached $1.3 \%$ of efficiency in bodipy:PCBM ${ }_{55} \mathrm{BHJ}$ devices (Figure 13). Using the same family of dyes, these authors $^{59}$ built BHJ devices with both Bodipy donors which display complementary absorption properties in the visible range $\left(\lambda_{\max 1}=590 \mathrm{~nm}, \lambda_{\max 2}=675 \mathrm{~nm}\right)$. This strategy has allowed to solve the problem of the narrow absorption of 60 these organic molecular dyes. An efficiency of $1.7 \%$ has been described with this multidonor BHJ, which represents an increase of $0.4 \%$ compared to the best efficiency described with a single Bodipy donor. This significant increase nicely illustrate the importance of harvesting sunlight in the whole 65 solar spectrum in order to obtain more efficient photovoltaic systems.

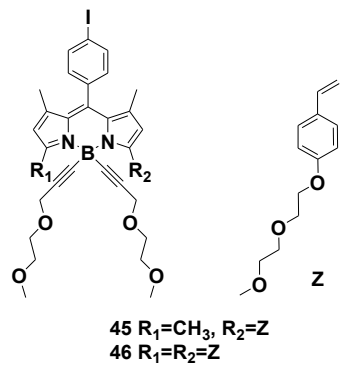

Figure 13. Bodipy dyes used for PV devices by blending with PCBM.

70 Using a similar strategy, some of us have described a new organic salt (49) by association of two NIR absorbing cyanine dyes $(\mathbf{4 7 , 4 8})$, which exhibit a good solubility in organic solvents (Figure 14). ${ }^{60}$ As a result of the combination of the two cyanines, the complex is able to absorb light in a broad range of the solar 75 spectrum $(650-950 \mathrm{~nm})$ displaying outstanding light harvesting properties in the NIR region with giant extinction coefficients. In preliminary experiments, the sun to power conversion efficiency obtained for the cyanine-cyanine complex:[60]PCBM (PCE = $0.4 \%$ ) was higher than the efficiency observed for blends of ${ }_{80}$ PCBM:cyanine-47 or PCBM:cyanine-48. This result indicates that the new dye is an appealing system for further studies as light harvester for photovoltaics 


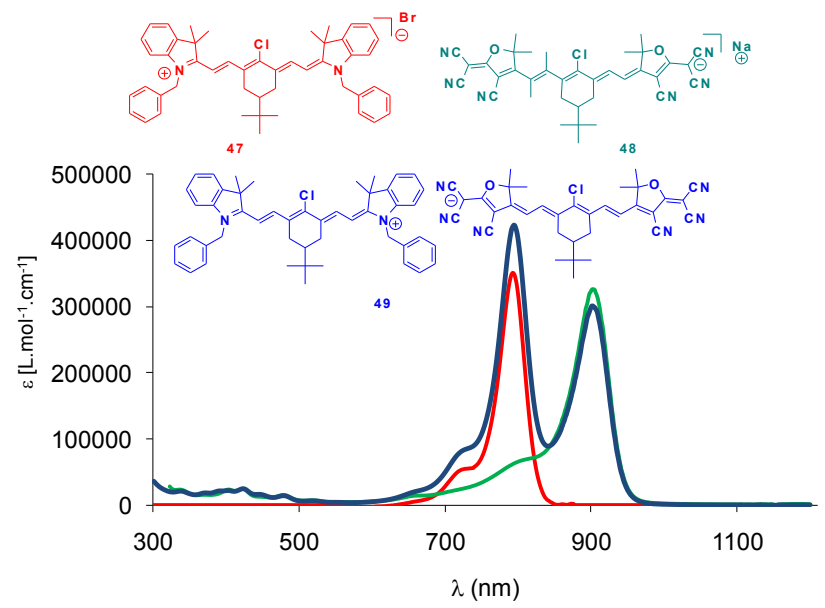

Figure 14. UV-vis spectra and structures of the cyanines blended with PCBM for PV devices.

iv) Organic Solar Cells with Innovative Carbon 5 Nanostructures

As mentioned above, one of the fundamental limitations of OPV device PCEs has been the molecular orbital offset between the available donor and acceptor materials. ${ }^{4}$ Toward this goal, new acceptor materials systems are being designed 10 and synthesized to optimize the donor/acceptor energy levels in orden to increase the device photovoltage. From the variety of nanoscale size shapes with fascinating properties that carbon is able to provide, ${ }^{61}$ carbon nanotubes (CNTs) ${ }^{62}$ and endohedral fullerenes ${ }^{63}$ are of current interest because of their 15 promising applications in next-generation organic photovoltaics, due to their outstanding intrinsic electronic properties.

\section{a) Endohedral fullerenes}

Novel acceptor materials with LUMO energies closer to that 20 of the donor, such as the derivatives of metallo endohedral fullerenes $\mathrm{M}_{3} \mathrm{~N} @ \mathrm{C}_{80}$, where the choice of metal $(\mathrm{M}=\mathrm{Sc}, \mathrm{Y}$, $\mathrm{Gd}, \mathrm{Tb}, \mathrm{Dy}, \mathrm{Ho}, \mathrm{Er}, \mathrm{Tm}, \mathrm{Lu}$ ) allows the fine tunning of the LUMO levels, as well as, the absorptive coefficients of the fullerene species, offer the possibility of considerably increase 25 the PCE of OPV devices.

In preliminary investigations, $\quad \mathrm{Sc}_{3} \mathrm{~N} @ \mathrm{C}_{80}$ and $\mathrm{Y}_{3} \mathrm{~N} @ \mathrm{C}_{80}$ shown to be applicable as part of electron-donor/acceptor systems in combination with powerful donors such as ferrocene $^{64}$ or $\pi$-extended tetrathiafulvalene ${ }^{65}$ derivatives 30 (exTTFs) (Figure 15$) \quad(\mathbf{5 0}$ and $\mathbf{5 1}$ respectively). The photophysical investigations revealed a significant stabilization of the radical ion pair state of $\mathrm{Sc}_{3} \mathrm{~N} @ \mathrm{C}_{80^{-}}$ ferrocene when compared to an analogous $\mathrm{C}_{60}$-ferrocene dyad. $^{44}$

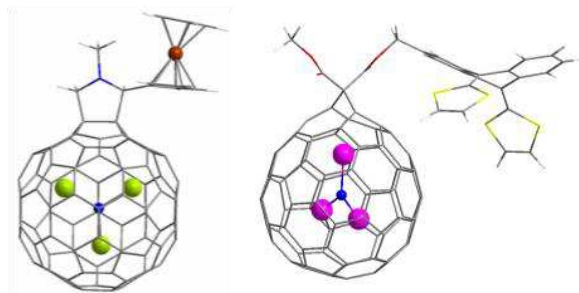

Figure 15. Optimized structures of a ferrocenene- $I_{h}-[5,6]-$ $\mathrm{Sc}_{3} \mathrm{~N} @ \mathrm{C}_{80}$ fulleropyrrolidine (50) (left) and the down isomer of an exTTF derivative of $[6,6]-I_{h^{-}}-Y_{3} N @ C_{80}(51)$ (Courtesy of Prof. J. M. Poblet).

40 These positive results have been recently complemented with the preparation of $\mathrm{BHJ}$ based solar cells considering a $\mathrm{Lu}_{3} \mathrm{~N} @ \mathrm{C}_{80}$ fulleroid modified with a phenyl butyric acid hexyl ester (52, PCBH) solubilizing group and, blended with P3HT. ${ }^{66}$ In photophysical experiments, the efficient charge 45 transfer between $\mathrm{P} 3 \mathrm{HT}$ and the $\mathrm{Lu}_{3} \mathrm{~N} @ \mathrm{C}_{80}-\mathrm{PCBH}$ were confirmed. The optimized $\mathrm{P} 3 \mathrm{HT} / \mathrm{Lu}_{3} \mathrm{~N} @ \mathrm{C}_{80}-\mathrm{PCBH}$ active layer morphology has resulted in OPV devices with $V_{o c}$ values as high as $890 \mathrm{mV}(260 \mathrm{mV}$ above reference devices made with $\mathrm{C}_{60}-\mathrm{PCBM}$ ) and a similar photocurrent and fill factor 50 compared to $\mathrm{P} 3 \mathrm{HT} / \mathrm{C}_{60}-\mathrm{PCBM}$ reference devices (Figure 16). The higher overall PCE (4.2\%) of the devices fabricated is attributed to a better positioned LUMO level that captures more of the energy associated with each absorbed photon. ${ }^{46}$ Further investigations, considering comparative analysis of 55 the film absoption and X-ray diffraction, indicate that the optimized blend ratio in a P3HT matrix differs from a molecular equivalent of an optimized $\mathrm{P} 3 \mathrm{HT} / \mathrm{C}_{60}-\mathrm{PCBM}$ active layer, and this is related to the physical differences of the $\mathrm{C}_{80}$ fullerene. ${ }^{67}$

60 Although additional investigations are necessary in the near future, the potential of endohedral metallofullerene species to enable optimized OPV devices is certainly very promising.
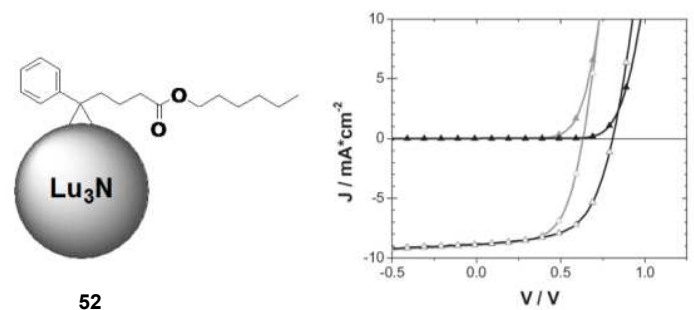

Figure 16. $\mathrm{Lu}_{3} \mathrm{~N} @ \mathrm{C}_{80}-\mathrm{PCBH} \quad$ (52) and current-voltaje 65 characteristics of $\mathrm{P} 3 \mathrm{HT} / \mathrm{Lu}_{3} \mathrm{~N} @ \mathrm{C}_{80}-\mathrm{PCBH}$ (black) and $\mathrm{P} 3 \mathrm{HT} / \mathrm{C}_{60}-\mathrm{PCBM}$ (grey). Solid triangles indicate the dark $J$ - $V$ curves and open triangles indicate the devices $J$ - $V$ curve under solar simulated iluumination. Reprinted from ref. 67 with permission from Wiley-VCH.

\section{${ }_{70}$ b) Carbon nanotubes}

Since their discovery CNTs have been a constant source for scientific motivation and in recent years have emerged as an oustanding class of carbon into OPVs. ${ }^{68}$ The most important stategies for implementing CNTs in OPV devices consider the 75 incorporation of single-walled carbon nanotubes (SWCNTs) in dye-sensitized solar cells (DSSC), their combination with 
semiconducting nanoparticles in quantum dot sensitized solar cells (QDSCs), or the preparation of polymer solar cells by blending CNTs with different organic polymers. Since the important class of $\operatorname{DSSC}^{69}$ is out of the scope of this work, in 5 this section we will mainly focus on those recent achievements whithin the two following type of cells:

\section{i) Quantum dot/CNTs solar cells}

Recently, hybrid nanocomposites consisting of CNTs and quantum dots (QDs) heterostructures have emerged as 10 excellent candidates for the fabrication of a novel class of PV devices because the nanoscale architectures play a very important role in improving the device performance of PV cells. $^{70,71}$

In a recent example, PV cells were fabricated utilizing hybrid 15 nanocomposites with side-wall attached ZnSe coated CdSe QDs onto the surface of oxidized multi-walled carbon nanotubes (MWCNTs). The $I-V$ characteristics of Al/(CdSe/ZnSe) QD-SWCNT hybrid conjugate/PEDOT:PSS /ITO PV cells were investigated under illumination with an 20 ultraviolet (UV) lamp (6W, $365 \mathrm{~nm})^{72}$ and the estimated PCE was $0.34 \%$. Considering the very large energy barrier between CdSe/ZnSe QDs and PEDOT:PSS, the performance of the PV cell is expected to be enhanced with structure optimization.

\section{ii) CNTs in polymer solar cells}

${ }_{25}$ CNTs have been usually incorporated into active layers of polymer solar cells by the dispersion of CNTs in a solution of an electron-donating conjugated polymer, such as polythiophene or poly( $p$-phenylene-vinylene) (PPV) derivatives, and spin-coating the composites onto a 30 transparent conductive electrode, typically ITO, covered with a hole-blocking layer. ${ }^{73}$

Friend et al. described the first investigation on the electronic properties of the composite formed by MWCNTs and PPV derivatives. ${ }^{73 a}$ On the other hand, Kymakis et al. demonstrated 35 an increase in the cell performance by blending poly(3octylthiophene) (P3OT) with only 1 wt $\%$ of SWCNTs. ${ }^{73 b}$ Since their pioneering work, many groups have exploited NTs in bulk heterojunction solar cells. ${ }^{48,73 c, 74}$ However, the power conversion efficiencies of polymer-CNT solar cells are as 40 high as ca. $1 \%$, which is much lower than typical values of high-performance bulk heterojunction solar cells (3-6\%) with a combination of $\pi$-conjugated polymers and fullerene derivatives including $\mathrm{PCBM}^{26}$ or DPMs. ${ }^{34,35}$

When blending CNTs with different polymers, one of the 45 major issues is to properly disperse the CNTs whithin the polymer matrix. In this sense, the addition of appropriate functional groups to the CNTs may result in a form compatible with the conjugated polymer. To this end, a $\mathrm{C}_{60^{-}}$ SWCNT complex has recently been synthesized via a so microwave induced functionalization approach and used as component of the photoactive layer in a bulk heterojunction photovoltaic cell (Figure 17). ${ }^{75}$ When compared to a control device with only $\mathrm{C}_{60}$ and P3HT, the addition of SWCNTs resulted in an improvement of both $J_{s c}$ and $\mathrm{FF}$, with power 55 conversion efficiency, by as much as $78 \% .^{76}$
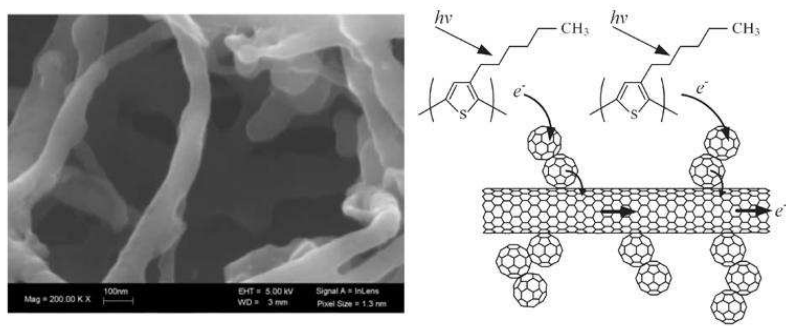

Figure 17. SEM image of the $\mathrm{C}_{60}$-complex prepared by microwave irradiation. The photoinduced charge separation at the polymer- $\mathrm{C}_{60}$ interface is followed by electron transfer ${ }_{60}$ from $\mathrm{C}_{60}$ to SWCNTs. The SWCNT netwok provides a direct path for faster electron transport towards the electrode. Reproduced from ref. 75 by permission of The Royal Society of Chemistry.

In recent years, several groups have investigate the possibility 65 of employ CNTs as a flexible replacement for ITO, ${ }^{77}$ since high quality ITO is expensive due to the resource constraint of indium. In addition, ITO is not compatible with roll-to-roll fabrication processing in contrast with today's market requirements for a full printable solar cell. For example,

${ }_{70}$ Rowell et al. demonstrated that SWCNts based hole-collecting electrodes show well above $80 \%$ of the performance of classical ITO electrodes, and allow a significant higher bending stress than ITO based plastic substrates. ${ }^{77 a}$ Thus, corrected power conversion efficiencies of $2.5 \%$ were 75 presented and the slight power loss in comparison to test devices using ITO contacts was mainly attributed to the increase serial resistance.

In order to improve the practical applications of CNTs in OPV devices, several aspects need to be consider: charge 80 recombination pathways, exciton dissociation, solubility and, which is probably the major challenge, the selective preparation of semiconducting SWCNTs. In this sense, in the past year important improvements have been reported towards the selective separation of semiconducting vs metallic CNTs 85 by means of chemical functionalization ${ }^{78}$ or microwave irradiation. $^{79}$

\section{Conclusions and outlook}

The most significant organic compounds prepared so far to be used in all-organic solar cells have been presented in a 90 systematic way. Bulk heterojunction plastic solar cells constituted by a semiconducting electron donor $\pi$-conjugated polymer and a fullerene as the acceptor moiety are currently the most promising devices for practical applications. The most remarkable achievements in $\pi$-conjugated polymers 95 have been presented as well as those modified fullerenes which, by blending with the appropriate polymers, have afforded the best energy conversion efficiencies reported so far, reaching values as high as $7.4 \%$.

Covalently connected $\pi$-conjugated polymers-fullerene 100 forming the so-called double-cable approach represents an elegant methodology to prepare new materials which, up to now, has afforded comparatively very low energy conversion efficiencies.

Molecular bulk heterojunction represents an interesting 
alternative to the use of polymers for the preparation of PV devices. These compounds have been classified in those systems formed by $\pi$-conjugated oligomers or dendrimers and fullerenes, and the most recent dyes blended with fullerenes.

${ }_{5}$ Other carbon nanostructures such as endohedral fullerenes and carbon nanotubes are promising materials for PV devices. Although so far only a couple of examples are known on PV devices involving endofullerenes, the high energy conversion efficiency $(4.2 \%)$, similar to that found for the efficient 10 [60]PCBM make these materials good candidates for further studies. Obviously, the main problem of these endofullerenes is currently related with their availability in larger scale.

Regarding the use of CNTs, it is important to note that the fate of these carbon nanoforms for PV devices depends primarily

15 on the separation of the metallic and semiconducting types of CNTs which typically are mixed in the commercially available materials. Although still low efficiencies have been reported with CNTs, the huge potencial of these carbon allotropes makes them very appealing in this field.

${ }_{20} \mathrm{~A}$ most important matter in all the above materials for improving the cell performance is the precise control of the energy levels of donor and acceptor components as well as the network morphology to maximize the mobility of the charge carriers. In this regard the realization of nano-structured 25 materials by means of a bottom-up supramolecular organization is currently in its infancy ${ }^{80}$ and, therefore, more work is need for improving the materials used for PV applications.

In summary, organic solar cells are call to play an important 30 role for satisfying the increasingly energy demanding of our society. Because of their features of low cost, flexibility and ligthness, these new PV cells - which should nicely complement the commercially available silicon cells - are very appealing for a variety of new practical purposes. The

35 outstanding achievements obtained so far put these solar cells closer to the market.

\section{Acknowledgements}

This work has been supported by the European Science Foundation (SOHYD, MAT2006-28170-E), the MEC of Spain 40 (CT2008-00795/BQU, and Consolider-Ingenio 2010C-0725200, Nanociencia Molecular) and Comunidad de Madrid (MADRISOLAR-2, S2009/PPQ-1533). S.F. and J.L.D. thanks the MICINN of Spain for a Ramón y Cajal Fellowship, cofinanced by the EU Social Funds. P.A.B. thanks IMDEA45 Nanociencia for a postdoctoral research grant.

\section{Notes and References}

${ }^{a}$ Departamento de Química Orgánica,Facultad de Ciencias Químicas, Universidad Complutense de Madrid, Ciudad Universitaria s/n, 28040 , Madrid (Spain,) Fax: (+34) 91-394-4103, ; Tel: (+34) 91-394-4227; 50 E-mail: nazmar@quim.ucm.es

${ }^{b}$ IMDEA-Nanociencia, Facultad de Ciencias, Módulo C-IX, $3^{a}$ planta, Ciudad Universitaria de Cantoblanco, 28049 Madrid.

1 (a) N. Armaroli, V. Balzani, Angew. Chem. Int. Ed. 2007, 46, 52; (b) For further information about solar energy, see the International Energy Agency Photovoltaic Power Systems Program at: www.ieapvps.org.
2 D. M. Chapin, C. S. Fuller and G. L. Pearson, J. Appl. Chem., 1954, 25, 676.

3 For some very recent special issues, see: (a) Special issue on "Organic Photovoltaics", J.-L. Bredas, J. R. Durrant, eds. Acc. Chem., Res. 2009, 42, 1689; (b) Special issue on "Renewable Energy", D. Nocera, D. M. Guldi, eds. Chem. Soc. Rev., 2009, 38, 1; (c) Special issue on "Chemistry of Renewables" R. Rinaldi, F. Schüth eds. ChemSusChem., 2009, 2, 1057; (d) Special issue on "Chemistry and Energy in the $21^{\text {st }}$ Century", E. Palomares, ed. ChemSusChem., 2009, 2, 265.

4 For some recent reviews on Organic Photovoltaics, see: (a) G. Dennler, M. C. Scharber and Ch. J. Brabec, Adv. Mater. 2009, 21, 1; (b) B. Kippelen and J.-J. Brédas, Energy Environ. Sci. 2009, 2, 251; (c) B. C. Thompson and J. M. J. Fréchet, Angew. Chem. Int. Ed. 2008, 47, 58; (d) S. Gunes, H. Neugebauer, N. S. Sariciftci, Chem. Rev. 2007, 107, 1324

5 For more information on these fundamental steps in the functioning of organic solar cells, see references 3 and 4. See also: C. J. Brabec, V. Dyakonov, U. Dcherf, "Organic Photovoltaics: Materials, Device Physics and Manufacturing Technologies". Wiley-VCH Verlag GmbH \&co. KGaA; Weinheim, Germany, 2008.

6 R. Po, M. Maggini, N. Camaioni, J.Phys. Chem. 2010, 114, 695.

7 (a) The Chemistry of Fullerenes, A. Hirsch, Wiley-VCH, Weinheim, Germany, 2005; (b) Fullerenes: From Synthesis to Optoelectronic Properties; (Eds. D. M. Guldi, N. Martín), Kluwer Academic Publishers: Dordrecht, The Netherlands, 2002; (c) Lecture Notes on Fullerene Chemistry: A Handbook for Chemists, R. Taylor, Imperial College Press, London, 1999; (d) Fullerenes. Principles and Applications (Eds. F. Langa and J.-F. Nierengarten), RSC, Cambridge, UK, 2007; (e) N. Martín, Chem. Commun. 2006, 2093.

8 (a) G. Li,, V. Shrotriya, J. Huang, Y. Yao, T. Moriarty, K. Emery, Y. Yang, Nat. Mater. 2005, 4, 864; (b) W. Ma, C. Yang, X. Gong, K. Lee, A. J. Heeger, Adv. Funct. Mater. 2005, 15, 1617.

9 (a) Fullerene Polymers. Synthesis, Properties and Applications; (Eds. N. Martín and F. Giacalone), Wiley-VCH, Weinheim, Germany, 2009; (b) F. Giacalone, N. Martín, Chem. Rev. 2006, 106, 5136.

10 L. H. Slooff, S. C. Veenstra, J. M. Kroon, D. J. D. Moet, J. Sweelssen, M. M. Koetse, Appl. Phys. Lett. 2007, 90, 143506.

11 F. Zhang, W. Mammo, L. M. Andersson, S. Admassie, M. R. Andersson, O. Ingana"s, Adv. Mater. 2006, 18, 2169.

12 N. Blouin, A. Michaud, M. Leclerc, Adv. Mater. 2007, 19, 2295

13 D. Mühlbacher, M. Scharber, M. Morana, Z. Zhu, D. Waller, R. Gaudiana, C. J. Brabec, Adv. Mater. 2006, 18, 2884.

14 M. M. Wienk, M. G. R. Turbiez, M. P. Struijk, M. Fonrodona, R. A. J. Janssen, Appl. Phys. Lett. 2006, 88, 153511.

15 W.-Y. Wong, X.-Z. Wang, Z. He, A. B. Djurisic, C.-T. Yip, K.-Y. Cheung, H. Wang, C. S. K. Mak, W.-K. Chan, Nat. Mater. 2007, 6, 521.

16 J. Hou, H.-Y. Chen, S. Zhang, R. I. Chen, Y. Yang, Y. Wu and G. Li, J. Am. Chem. Soc. 2009, 131, 15586.

17 R. Qin, W.Li, C. Li, C. Du, C. Veit, H.-F. Schleiermacher, M. Andersson, Z. Bo, Z. Liu, O. Inganas, U. Wuerfel, and F. Zhang, J. Am. Chem. Soc., 2009, 131, 14612.

18 Y. Liang, Z. Xu, J. Xia, S.-T. Tsai, Y. Wu, G. Li, C. Ray and L. Yu, Adv. Mater. 2010, 22, 1.

19 (a) F. Zhang, W, Mammo, L. M. Andresson, S. Admassie, M. R. Andresson, O. Inganäs, Adv. Mater. 2006, 18, 2169; (b) O. Inganäs, F. Zhang, M. R. Andersson, Acc. Chem. Res. 2009, 42, 1731.

20 (a) G. Dennler, N. S. Sariciftci, C. J. Brabec, in "Semiconducting Polymers", $2^{\text {nd }}$ ed. (Eds. G. Hadziioannou, G. G. Malliaras), WileyVCH, Weinheim, Germany, 2006; (b) J. Chen, Y. Cao, Acc. Chem. Res. 2009, 42, 1709; c) Y.J. Cheng, S. H. Yang, C.S. Hsu, Chem. Rev. 2009, 109, 5868.

21 G. Zerza, M. C. Scharber, C. J. Brabec, N. S. Saricftci, R. Gómez, J. L. Segura, N. Martín, V. I. Srdanov, J. Phys. Chem. A, 2000, 104, 8315.

22 (a) C. Waldauf, W. Graupner, S. Tasch, G. Leising, A. Gügel, U. Scherf, A. Kraus, M. Walter, K. Müllen, Opt. Mater. 1998, 9, 449. (b) For a recent review involving exTTF as a donor, see: N. Martín, 
L. Sánchez, M. A. Herranz, B. Illescas, D. M. Guldi, Acc. Chem. Res. 2007, 40, 1015.

23 (a) J.-F. Nierengarten, J.-F. Eckert, J.-F. Nicoud, L. Ouali, V. Krasnikov, G. Hadziioannou, Chem. Commun. 1999, 617; (b) J.-F. Eckert, J.-F. Nicoud, J.-F. Nierengarten, S.-G. Liu, L. Echegoyen, F. Barigelletti, N. Armaroli, L. Ouali, V. Krasnikov, G. Hadziioannou, J. Am. Chem. Soc. 2000, 122, 7467; (c) D. M. Guldi, Ch. Luo, A. Swartz, R. Gómez, J. L. Segura, N. Martín, C. Brabec, N. S. Saricftci, J. Org. Chem. 2002, 67, 1141; (d) C. Atienza, G. Fernández, L. Sánchez, N. Martín, I. S. Dantas, M. M. Wienk, R. A. J. Janssen, G. M. A. Rahman, D. M. Guldi, Chem. Commun. 2006, 514. (d) G. Fernández, L. Sánchez, D. Veldman, M. M. Wienk, C. Atienza, D. M. Guldi, R. A. J. Janssen, N. Martín, J. Org. Chem. 2008, 73, 3189.

24 K. Felddrap, W. Brütting, M. Schoerer, M. Brettreich, A. Hirsch, Synth. Met. 1999, 101, 156 .

25 M. T. Rispens, J. C. Hummelen, in "Fullerenes: From Synthesis to Optoelectronic Properties". D. M. Guldi, N. Martín, eds. Kluwer Acad. Publishers. Ch. 12, pp 387-435. Dordrech, The Netherlands, 2002.

26 J. C. Hummelen, B. W. Knight, F. LePeq, F. Wudl, J. Yao, C. L. Wilkins, J.Org. Chem. 1995, 60, 532.

27 G. Yu, J. Gao, J. C. Hummelen, F. Wudl, A. J. Heeger, Science, 1995, 270, 1789.

28 (a) Y. Zhang, H. L. Yip, O. Acton, S. K. Hau, F. Huang, A. KY. Jen, Chem. Mater. 2009, 21, 2598; (b) Ch. Yang, J. Y. Kim, Sh. Cho, J. K. Lee, A. J. Heeger, F. Wudl J. Am. Chem. Soc. 2008, 130, 6444; (c) Kooistra, F. B.; Knol, J.; Kastenberg, F.; Popescu, L. M.; Verhees, W. J. H.; Kroon, J. M.; Hummelen, J. C. Org. Lett. 2007, 9, 551;(d) M. Drees, H. Hoppe, C. Winder, H. Neugebauer, N. S. Sariciftci, W. Schwinger, F. Schäffler, C. Topf, M. C. Scharber, Z. Zh, R. Gaudiana, J. Mater. Chem. 2005, 15, 5158; (e) L. Zheng, Q. Zhou, X. Deng, M. Yuan, G. Yu, Y. Cao, J. Phys. Chem. B, 2004, 108, 11921; (f) L. M. Popescu, P. van 't Hof, A. B. Sieval, H. T. Jonkman, J. C. Hummelen, Appl. Phys. Lett., 2006, 89, 213507.

29 (a) F. B. Kooistra, J. Knol, F. Kastenberg, L. M. Popescu, W. J. H. Verhees, J. M. Kroon, J. C. Hummelen, Org. Lett. 2007, 9, 551; (b) M. Lenes, G.-J. A. H. Wetzelaer, F. B. Kooistra, S. C. Veenstra, J. C. Hummelen, P. W. M. Blom, Adv. Mater. 2008, 20, 2116.

30 M. M. Wienk, J. M. Kroon, W. J. H. Verhees, J. Knol, J. C.Hummelen, P. A. van Hal, R. A. J. Janssen, Angew. Chem. Int. Ed. 2003, 42, 3371.

31 S.H. Park, A. Roy, S. Beaupré, S. Cho, N. Coates, J.S. Moon, D. Moses, M. Leclerc, K. Lee, A. J. Heeger. Nat. Photonics, 2009, 3, 297.

32 F. B. Kooistra, V. D. Mihailetchi, L. M. Popescu, D. Kronholm,P.W. M. Blom, J. C. Hummelen, Chem. Mater., 2006, 18, 3068.

33 X. Wang, E. Perzon, J.L. Delgado, P. de la Cruz, F. Zhang, F. Langa, M. Andersson, and O. Inganäs, Appl. Phys. Lett. 2004, 85, 5081; b) E. Perzon, X. Wang, F. Zhang, W. Mammo, J.L. Delgado, P. de la Cruz, O. Inganas, F. Langa and M. R. Andersson, Synth. Met., 2005, 154, 53.

34 I. Riedel, E. von Hauff, J. Parisi, N. Martín, F. Giacalone V. Diakonov, Adv. Funct. Mater., 2005, 15, 1979.

35 I. Riedel, N. Martín, F. Giacalone, J.L. Segura, D. Chirvase, J. Parisi, V. Diakonov, Thin Solid Films, 2004, 43, 451.

36 S. Backer, K. Sivula, D. F. Kavulak, J. M. J. Fréchet, Chem. Mater. 2007, 19, 2927.

37 R. D. Kennedy, A. L. Ayzner, D. D. Wanger, C. T Day, M. Halim, S. I. Khan, S. H. Tolbert, B. J. Schwartz, Y. Rubin, J. Am. Chem. Soc., 2008, 130, 17290.

38 (a) For a review on fullerene dimers, see: J. L. Segura, N. Martin, Chem. Soc. Rev. 2000, 29, 13; (b) J. L. Segura, E. M. Priego, N. Martín, C. P. Luo, D. M. Guldi, Org. Lett. 2000, 2, 4021; (c) J. J. González, S. González, E. M. Priego, C. P. Luo, D. M. Guldi, J. de Mendoza, N. Martín, Chem. Commun. 2001, 163.

39 J.L. Delgado, E. Espíldora, M. Liedtke, A. Sperlich, D. Rauh, A. Baumann, C. Deibel, V. Dyakonov, N. Martín, Chem. Eur. J., 2009, 15, 13474 .

40 (a) J.L. Delgado, F. Cardinali, E. Espíldora, M.R. Torres, F. Langa, and N. Martín, Org. Lett. 2008, 10, 3705; ( b) J. L. Delgado, F.
Oswald, F. Cardinali, F. Langa, N. Martín, J. Org. Chem. 2008, 73, 3184.

41 (a) M. Maggini, G. Scorrano, M. Prato, J. Am. Chem. Soc. 1993, 115 , 9798; (b) M. Prato, M. Maggini, Acc. Chem. Res. 1998, 31, 519; (c) N. Tagmatarchis, M. Prato, Synlett, 2003, 768.

42 Y. He, H.-Y. Chen, J. Hou, Y. Li, J. Am. Chem. Soc. 2010, 132, 1377.

43 A. Marcos Ramos, M. T. Rispens, J. K. J. van Duren, J. C. Hummelen, R. A. J. Janssen, J. Am. Chem. Soc. 2001, 123, 6714

44 (a) A. Cravino, S. Sariciftci, J. Mater. Chem. 2002, 12, 1931; (b) A. Cravino, S. Sariciftci, Nature Mater. 2003, 2, 360.

45 (a) A. Cravino, N. S. Sariciftci, "Polyfullerenes for Organic Photovoltaics" in Fullerene Polymers. Synthesis, Properties and Applications; (Eds. N. Martín and F. Giacalone), Wiley-VCH, Weinheim, Germany, 2009;

46 (a) F. Zhang, M. Svensson, M. R. Andersson, M. Maggini, S. Bucella, E. Menna, O. Ingänas, Adv. Mater. 2001, 13, 1871; (b) Tan, Z.; Hou, J.; He, Y.; Zhou, E.; Yang, C.; Li, Y. Macromolecules 2007, 40, 1868.

47 C. Yang, J: Kwan Lee, A. J. Heeger, F. Wudl, J. Mater. Chem., 2009, 19, 5416.

48 J. Roncali, Acc. Chem. Res., 2009, 42, 1719.

49 C. Soci, I-W Hwang, D. Moses, Z. Zhu, D. Walter, R. Guadiana, C.J. Brabec and A.J. Heeger, Adv. Funct. Mater, 2007, 17, 632.

50 J. L. Segura, N. Martín, D. M. Guldi, Chem. Soc. Rev., 2005, 34, 31.

51 X. Sun, Y. Zhou, W. Wu, Y. Liu, W. Tian, G. Yu, W. Qiu, S. Chen, D. Zhu, J. Phys. Chem. B, 2006, 110, 7702.

52 A.B. Tamayo, X.D. Dang, B. Walker, J. Seo, T. Kent and T.Q. Nguyen, Appl. Phys. Lett., 2009, 94, 103301.

53 .a) C.-Q. Ma, E. Mena-Osteritz, T. Debaerdemaeker, M.M. Wienk, R.A.J. Janssen and P. Bäuerle, Angew. Chem. Int. Ed., 2007, 46, 1679; b) C.-Q. Ma, M. Fonrodona, M.C. Schikora, M.M. Wienk, R.A.J. Janssen and P. Baüerle, Adv. Func. Mater. 2008, 18, 3323.

54 S. Roquet, A. Cravino, P. Leriche, O. Alvque, P. Fre and J. Roncali, J. Am. Chem. Soc., 2006, 128, 3459.

55 N.M. Kronemberg, M. Deppisch, F. Würthner, H.W.A. Lademan, K. Deing and K. Meerholz, Chem. Commun., 2008, 6489.

56 F. Silvestri, M.D. Irwin, L. Beverina, A. Facchetti, G.A. Pagani and T.J. Marks, J. Am. Chem. Soc., 2008,130, 17640.

57 U. Mayerhöffer, K. Deing, K. Grub, H. Braunschweig, K. Meerholz and F. Würthner, Angew. Chem. Int. Ed., 2009, 48, 1.

58 T. Rousseau, A. Cravino, T. Bura, G. Ulrich, R. Ziessel and J. Roncali, Chem. Commum., 2009, 1673.

59 T. Rousseau, A. Cravino, T. Bura, G. Ulrich, R. Ziessel and J. Roncali, J. Mater. Chem, 2009, 19, 2298.

60 P.A. Bouit, D. Rauh, S. Neugebauer, J.L. Delgado, E. Di Piazza, S. Rigaut, O. Maury, C. Andraud, V. Dyakonov and N. Martín, Org. Lett, 2009, 11, 4806.

61 J. L. Delgado, M. A. Herranz and N. Martín, J. Mater. Chem., 2008, 18, $1417-1426$.

62 For recent reviews on the electronic properties of carbon nanotubes, see: (a) D. M. Guldi, G. M. A., Rahman, V. Sgobba and C. Ehli, Chem. Soc. Rev., 2006, 35, 471; (b) D. M. Guldi, Phys. Chem. Chem. Phys., 2007, 1400; (c) V. Sgobba and D. M. Guldi, Chem. Soc. Rev., 2009, 38, 165.

63 For recent reviews on endohedral fullerenes, see: (a) L. Dunsch and S. Yang, Small, 2007, 3, 1298. (b) M. N. Chaur, F. Melin, A. L. Ortiz and L. Echegoyen, Angew. Chem. Int. Ed., 2009, 48, 7514. (c) M. Yamada, T. Akasaka and S. Nagase, Acc. Chem. Res. 2010, 43, 92.

64 J. R. Pinzón, M. E. Plonska-Brzezinska, C. M. Cardona, A. JAthans, S. S. Gayathri, D. M. Guldi, M. A. Herranz, N. Martín, T. Torres and L. Echegoyen, Angew. Chem. Int. Ed., 2008, 47, 4173.

65 J. R. Pinzón, C. M. Cardona, M. A. Herranz, M E. PlonskaBrzezinska, A. Palkar, A. J. Athans, N. Martín, A. Rodríguez-Fortea, J. M. Poblet, G. Bottari, T. Torres, S. S. Gayathri, D. M. Guldi and L. Echegoyen, Chem. Eur. J., 2009, 15, 864.

66 R. B. Ross, C. M. Cardona, D. M. Guldi, S. S. Gayathri, M. O. Reese, N. Kopidakis, J. Peet, B. Walker, G. C. Bazan, E. Van Keuren, B. C. Holloway and M. Drees, Nature Mat., 2009, 8, 208. 
67 R. B. Ross, C. M. Cardona, F. B. Swain, D. M. Guldi, S. S. Gayathri, E. Van Keuren, B. C. Holloway and M. Drees, Adv. Funct. Mater., 2009, 19, 2332.

68 (a) V. Sgobba and D. M. Guldi, J. Mater. Chem., 2008, 153. (b) T. Umeyama and H. Imahori, Energy Environ. Sci., 2008, 1, 120.

69 (a) B. O'Regan, M. Grätzel, Nature, 1991, 353, 737; (b) M. Grätzel, Acc. Chem. Res., 2009, 11, 1788.

70 P. R. Somani, S. P. Somani, M. Umeno, Appl. Phys. Lett., 2008, 93, 033315.

71 B. Farrow, P. V. Kamat, J. Am. Chem. Soc., 2009, 131, 11124.

72 F. Li, D. I. Son, T. Whan, Kim, E. Ryu, S. W. Kim, S. K. Lee, Y. H. Cho, Appl. Phys. Lett., 2009, 95, 061911.

73 (a) H. Ago, K. Petritsch, M. S. P. Shaffer, A. H. Windle and R. H. Friend, Adv. Mater., 1999, 11, 1281; (b) E. Kymakis, E. Stratakis and E. Koudoumas, Thin Solid Films, 2007, 515, 8589; (c) S. Berson, R. Bettingbies, S. Bailly, S. Guillerez and B. Jousselme, Adv. Func. Mater, 2007, 17, 3363.

74 H. Hoppe and N. S. Sariciftci, Adv. Polym. Sci., 2008, 214, 1.

75 C. Li, Y. Chen, Y. Wang, Z. Iqbal, M. Chlowalla, S. Mitra, J. Mater. Chem., 2007, 17, 2406.

76 C. Li, S. Mitra, Appl. Phys. Lett., 2007, 91, 253112.

77 (a) M. W. Rowell, M. A. Topinka, M. D. McGehee, H. J. Prall, G. Dennler, N. S. Sariciftci, L. B. Hu and G. Gruner, Appl. Phys. Lett., 2006, 88, 233506; (b) A. D. Pasquier, H. E. Unalan, A. Kanwal, S. Millerand M. Chhowalla, Appl. Phys. Lett., 2006, 87, 203511.

78 M. Kanungo, H. Lu, G. G. Malliaras and G. B. Blanchet, Science, 2009, 323, 234.

79 (a) H. Qiu, Y. Maeda and T. Akasaka, J. Am. Chem., 2009, 131, 16529; (b) E. Vázquez, M. Prato, ACS Nano, 2009, 3, 3819.

80 (a) D. Écija, R. Otero, L. Sánchez, J. M. Gallego, Y. Wang, M. Alcamí, F. Martín, N. Martín, R. Miranda, Angew. Chem. Int. Ed. 2007, 46, 7874; (b) R. Otero, D. Écija, G. Fernánez, J. M. Gallego, L. Sánchez, N. Martín, R. Miranda, Nano Lett. 2007, 7, 2602. (c) See also: L. Sánchez, R. Otero, J. M. Gallego, R. Miranda, N. Martín, Chem. Rev. 2009, 109, 2081. 